\title{
Hydraulic Redistribution from Wet to Drying Roots of Potatoes (Solanum tubersosum L.) During Partial Rootzone Drying
}

by Saeed, H., Grove, I.G., Kettlewell, N.W., Fairchild, I.J. and Boomer, I.

Copyright, Publisher and Additional Information: Publishers version distributed under the terms of the Creative Commons Attribution License:

https://creativecommons.org/licenses/by/4.0/

DOI: $10.4172 / 2329-8863.1000162$

Harper Adams

University 


\title{
Hydraulic Redistribution from Wet to Drying Roots of Potatoes (Solanum tubersosum L.) During Partial Rootzone Drying
}

Hamad Saeed $^{1 *}$, Ivan G. Grove ${ }^{2}$, Peter S. Kettlewell ${ }^{2}$, Nigel W. Hall ${ }^{2}$, lan J. Fairchild ${ }^{3}$ and lan Boomer ${ }^{3}$

${ }^{1}$ Department of Agriculture, Wiltshire College, Lacock, Chippenham, Wiltshire, UK

${ }^{2}$ Crop and Environment Research Centre, Harper Adams University College, Newport, Shropshire, UK

${ }^{3}$ School of Geography, Earth and Environmental Sciences, University of Birmingham, UK

\begin{abstract}
Hydraulic redistribution, redistribution of water upward or downward within a soil profile through roots as a consequence of root-soil water potential gradients, can be an important mechanism in transporting chemical signals (i.e. abscisic acid) to the shoot for stomatal closure or in maintaining the root system during dry periods of partial rootzone drying (PRD). PRD involves alternate irrigation to two sides of a plant root system. The study reported here investigated the occurrence and magnitude of hydraulic redistribution in glasshouse-grown potatoes (Solanum tuberosum L.) under PRD. Deuterium labelled water was applied to only one half of the root system to field capacity at tuber initiation. The roots from the drying side of the dual pot were extracted at 3,6 , 12,18 and $24 \mathrm{~h}$ following watering by the dry sieving method. Water from the roots was extracted by azeotropic distillation and analysed for hydrogen isotope ratios. Hydraulic redistribution occurred the most at night when stomatal conductance was considerably lower and leaf water potential was higher (less negative). The magnitude of the redistributed water, however, did not exceed 3.5\%, indicating limited water redistribution under PRD. The observed water redistribution would probably be of little significance for the survival of roots present in the upper drier portion of the soil under higher water demanding conditions but its role in sending the chemical signals to the shoot to conserve water by reducing transpiration would be of particular significance during drying periods of partial rootzone drying.
\end{abstract}

Keywords: Potatoes; Partial rootzone drying; Hydraulic redistribution; Water utilization; Stomatal conductance; Leaf water potential

\section{Introduction}

Water is the most important factor controlling plant growth [1]. Plants shift growth in favour of roots under water deficit conditions [2]. Roots under water deficits continue growth by adjusting the minimum pressure in cells required for the expansion and by regulating solute transport within the elongation zone by altering cell wall elasticity or cell size $[3,4]$. This adoptive response to a water deficit results in vertical root penetration reaching the moist soil layers. Roots in the deeper moist soil layers often help plants to overcome drought stress by extracting and supplying more water to the shoot $[5,6]$. These roots can also redistribute water to the upper drier soil layers at night by a process known as hydraulic lift $[7,8]$. Although the direction of water movement is typically upward towards the shallower soil layers, it has been demonstrated that roots can also redistribute water from the surface to deep soil layers along water potential gradients $[9,10]$. The process is thought to be largely passive, requiring only a gradient in soil water potential, a more positive water potential in the root xylem than in the surrounding dry soil layers, and a relatively low resistance to reverse flow from the roots [11]. Because of the bidirectional and passive nature of the phenomenon, Burgess et al. [9] have proposed 'hydraulic redistribution' as a more comprehensive term for the phenomenon. This downward movement of water has also been described as 'downward siphoning' [12], 'inverse hydraulic lift' [13] or 'reverse flow' [10] in the literature. Scholz et al. [14] found that the rate of reverse flow was linearly related to soil-leaf water potential gradient, with the greatest reverse flow rates occurring when this potential gradient was at its most negative values. Hultine et al. [15] reported greater magnitude of hydraulic redistribution in roots when night-time vapour pressure deficit was low. The onset and the magnitude of hydraulic redistribution is thought to be regulated by the development of water potential gradients within the plant parts, between the plant parts and soil, and the nocturnal demand for water by the plant [16]. Hydraulically redistributed water may buffer plants against water stress during a water deficit by replenishing up to $28-35 \%$ of the soil water removed each day by plants from the upper soil layers [17]. The redistributed water can contribute positively in transporting chemical signals (i.e. abscisic acid) to the shoot for stomatal closure [18] or in prolonging or enhancing the activity (e.g. growth and solute uptake) and life span of fine roots in a dry soil profile [19,20], Hydraulic redistribution has been reported to be a common phenomenon in numerous plant species including trees, shrubs and grasses from deserts to tropical forests [21]. Little attention has been paid, however, to the phenomenon in agricultural crops. There has been a report documenting the occurrence of hydraulic redistribution in grapevines under partial rootzone drying (PRD) [18]. PRD is an irrigation practice in which one half of the plant root system is irrigated as in standard irrigation whilst the other half is kept in a drying state [22]. Results of this study are, however, inconclusive in terms of the extent to which

${ }^{*}$ Corresponding author: Hamad Saeed, Department of Agriculture, Wiltshire College, Lacock, Chippenham, Wiltshire, UK, Tel: $+44(0) 7590622741$; E-mail: hamadsaeed@yahoo.com

Received February 11, 2015; Accepted February 19, 2015; Published February 21, 2015

Citation: Saeed H, Grove IG, Kettlewell PS, Hall NW, Fairchild IJ, et al. (2015) Hydraulic Redistribution from Wet to Drying Roots of Potatoes (Solanum tubersosum L.) During Partial Rootzone Drying. Adv Crop Sci Tech 3: 162. doi:10.4172/2329-8863.1000162

Copyright: ( 2015 Saeed $\mathrm{H}$, et al. This is an open-access article distributed under the terms of the Creative Commons Attribution License, which permits unrestricted use, distribution, and reproduction in any medium, provided the original author and source are credited. 
hydraulic redistribution occurs to roots growing in the drying soil. Due to inadequate information on this subject, the degree of dependency of roots of the drying soil on roots of the wet soil under partial rootzone drying (PRD) is unknown. To date, there is no published work describing the detailed insight of the water-supplying characteristics of the wet roots to the roots of the drying soil under PRD. Further, until now hydraulic redistribution phenomenon has not been studied in potatoes (Solanum tuberosum L.) under partial rootzone drying. The present study investigated the hydraulic redistribution mechanism and its magnitude in potatoes (Solanum tuberosum L.) under partial rootzone drying using the stable isotope of hydrogen (deuterium). The hypothesis tested was that hydraulic redistribution does occur in potatoes during PRD and at an increased rate when transpiration is low. The objectives were to investigate (1) whether hydraulic redistribution occurs in potatoes during PRD, (2) the time of water movement from wet to the drying half of the root system, and (3) the magnitude of the redistributed water in the roots growing in the drying soil.

\section{Materials and Methods}

Potatoes (cv. Estima) with a split root system were grown in John Innes No. 2 compost in a dual flexible pot system under glasshouse conditions at Harper Adams University College, Shropshire, UK during April to June 2006. The dual flexible pot system was made by joining two flexible plant pots (LBS Polypot, LBS Horticultural Ltd., UK), each $18 \mathrm{~cm}$ wide and $30 \mathrm{~cm}$ tall with a volume of $6.11 \mathrm{~L}$. Seed tubers of the potato cv. Estima were placed in a suitably-sized hole created on the inner sides of the pot, $10 \mathrm{~cm}$ from the top, in such a way that half of the sprouts laid in each side of the pot. A $2 \mathrm{~cm}$ layer of gravel (6 $\mathrm{mm}$ diameter) was added at the surface after planting to prevent evaporation. Plant emergence was completed at $13 \pm 1$ days ( $\mathrm{n}=40 \pm$ standard deviation; S.D). All plants were thinned to a single shoot growing in the middle of the dual pot a week after plant emergence. The aim was to minimise root growth variability between the split root system and between the plants due to variable number of stems. Volumetric water content (\%) of the compost from both sides of a dual pot was monitored regularly with time domain reflectometry using Trime FM (Imko, Germany). Both sides of a dual pot were irrigated close to field capacity until tuber initiation. At tuber initiation (four weeks after plant emergence), plants were randomly assigned to different treatments in a complete block experiment. Treatments were the combination of two water types and five root sampling times with four replications of each treatment. Water types were tap water and deuterated water. Tap water was the normal irrigation water with an isotopic composition $(\delta 2 \mathrm{H})$ of -51 parts per thousand (\%). Deuterated water was prepared by mixing $10 \mathrm{ml}$ of deuterium oxide $(99.96 \%$ deuterium, Merck KGaA, Germany) in 40 litres of tap water. The $\delta 2 \mathrm{H}$ value of the deuterated water obtained was $1217(\%)$. The obtained $\delta 2 \mathrm{H}$ value was in the range of enrichment used for grapevines [18] and Douglas-fir trees [17]. Both types of water were applied in the morning between 08:00-09:00 $\mathrm{h}$ at a slow trickle, away from the stem base, to only one side of the dual pot to FC. The other side was kept in a drying state over the treatment period. Plants irrigated with tap water were denoted as 'control' plants whilst those irrigated with deuterated water were denoted as 'treated' plants. On average, control and treated plants received 1332 and $1353 \mathrm{ml}$ of tap water and deuterated water, respectively. Shortly after watering, the irrigated side was covered with aluminium foil to prevent deuterium fractionation due to surface evaporation. The movement of water from the base of irrigated to the drying side of a dual pot was eliminated by placing each side of the dual pot in a pot saucer. Soil water content was close to $25 \%$ by vol. in both sides of a dual pot at the time of water application. This corresponded to approximately $50 \%$ of FC, or to a soil matric potential of approximately $-150 \mathrm{kPa}$ according to the moisture release curve for this compost. Roots from drying side of a dual pot were extracted at 3 , $6,12,18$ and $24 \mathrm{~h}$ following watering. Root sampling times fell at local time 12:00, 15:00, 21:00, 03:00, and 09:00 h, respectively, allowing to determine the time and rate of water influx from irrigated to drying side of the root system under high (day) and low (night) evaporative demand conditions.

\section{Physiological measurements}

Physiological influences of PRD on the movement and magnitude of water redistribution were evaluated by measuring abaxial stomatal conductance and leaf water potential for each sampling time. Abaxial stomatal conductance was measured from the terminal leaflet of the $4^{\text {th }}$ fully expanded young leaf from the apex $[23,24]$ using a portable porometer (Delta-T AP4, Delta-T devices, Cambridge, UK). Leaf water potential was measured immediately after the stomatal conductance measurements on the same leaf within a minute of its excision using a Scholander portable pressure chamber [25]. The physiological measurements were completed within half an hour at any sampling time.

\section{Root extraction}

Roots from the drying side of a dual pot were extracted from compost by the dry sieving method [26]. Roots retained on the sieve $(5 \times 5 \mathrm{~mm}$ mesh size) were collected, washed with tap water to remove any compost traces, excess water removed immediately with filter paper, placed in self-seal plastic bags and stored at $0^{\circ} \mathrm{C}$ in a water bath to prevent isotopic fractionation due to evaporation [6]. Root samples were transported to the laboratory after each sampling time where they were stored at $-30^{\circ} \mathrm{C}$ until water extraction $[6,27]$. The root extraction time did not exceed one hour for any sampling time. Water extraction, purification and hydrogen isotope analysis Water from all root samples was extracted by azeotropic distillation with kerosene (liquid paraffin; boiling point $>23^{\circ} \mathrm{C}$, VWR Ltd. UK) as the solvent $[28,29]$ using the methods described by Revesz and Woods [30]. The water extraction process took 2-3 h to complete. Water samples were purified with powder paraffin wax (solidifying point $63-66^{\circ} \mathrm{C}$ ) for any impurities [3032]. The purified water samples were stored in $2 \mathrm{ml}$ vials at $-30^{\circ} \mathrm{C}[6,27]$. All water samples were sent to Isotope and Luminescence Laboratory, School of Geography, Earth and Environmental Sciences, University of Birmingham, UK for hydrogen isotope analysis. Water samples were analysed for hydrogen isotope ratios on a continuous flow isotope ratio mass spectrometer (Isoprime ${ }^{\mathrm{m} w}, \mathrm{GV}$ Instruments, Manchester,UK) interfaced with an elemental analyser (Eurovector, GV Instruments) and a autosampler. The hydrogen isotope ratios were expressed as $\delta 2 \mathrm{H}$ (delta values) in parts per thousand (\%) relative to V-SMOW (Vienna Standard Mean Ocean Water):

\section{$\delta 2 \mathrm{H}(\%)=[($ Rsample/RVSMOW $)-1] 1000$}

Where $\mathrm{R}_{\text {sample }}$ and $\mathrm{R}_{\mathrm{vSMOW}}$ are the ratios of deuterium to hydrogen atoms $\left({ }^{2} \mathrm{H} /{ }^{1} \mathrm{H}\right)$ of the isotope sample and the standard VSMOW, respectively. The total analytical uncertainty of the instrument was \pm $1 \%$.

\section{Proportion of deuterated water uptake (\%)}

The proportion of deuterated water taken up by the treated plants relative to the control plants was calculated using the following formula (pers. communication: Prof. Ian Fairchild, School of Geography, Earth and Environmental Sciences, University of Birmingham, UK): 
Citation: Saeed H, Grove IG, Kettlewell PS, Hall NW, Fairchild IJ, et al. (2015) Hydraulic Redistribution from Wet to Drying Roots of Potatoes (Solanum tubersosum L.) During Partial Rootzone Drying. Adv Crop Sci Tech 3: 162. doi:10.4172/2329-8863.1000162

Page 3 of 8

\section{Proportionof water uptake $=\frac{\text { Rtreated plant }- \text { Rcontrol plant }}{\text { Rdeuterated water }- \text { Rtap water }}$}

Where $\mathrm{R}_{\text {treated plant }}$ and $\mathrm{R}_{\text {control plant }}$ are the ratios of deuterium to hydrogen atoms $\left({ }^{2} \mathrm{H} /{ }^{1} \mathrm{H}\right)$ of the water extracted from a plant that received either deuterated or tap water, respectively. $\mathrm{R}_{\mathrm{d}}$ and $\mathrm{R}_{\text {tap water }}$ are the ratios of deuterium to hydrogen atoms $\left({ }^{2} \mathrm{H} /{ }^{1} \mathrm{H}\right)$ of deuterated and tap water applied to a plant, respectively. These proportions were expressed as percentages after multiplying by 100 .

\section{Water utilisation}

Water utilisation from either side of a dual pot was calculated by the following

Formula:

Water use (\%, vol.) of a side of a dual pot was calculated as follows

Water use $(\%$, vol. $)=\mathrm{WC}_{(\mathrm{s})}-\mathrm{WC}_{(\mathrm{E})}$

Where:

$\mathrm{WC}_{(\mathrm{S})}$ is the water content (\%, vol.) measured from a side of a dual pot when treatments began. WC(s) (\%, vol.) for the wet side of the pot was taken as $50.33 \%$ as this side was only irrigated to field capacity. $\mathrm{WC}_{(\mathrm{E})}$ is the water content (\%, vol.) measured at the end of a sampling time.

\section{Air temperature}

Air temperature during the treatment period was recorded by positioning a Tinytag ${ }^{\circledR}$ data logger (Gemini Data Loggers (UK) Ltd., Chichester, Sussex, UK) one metre above the plant canopy. The changes in temperature over each sampling time are shown in Figure 1.

\section{Statistical data and analysis}

During water application, approximately $500 \mathrm{ml}$ of deuterated water $\left(\delta^{2} \mathrm{H}=1217 \%\right)$ accidentally moved to the dry side of the pot (supposed not to receive this water) in one of the $3 \mathrm{~h}$ root sampling time plants, thus omitted from the experiment. Additionally, one water sample bottle of $12 \mathrm{~h}$ root sampling time damaged during storage, so was discarded in the isotope analysis. Data were subjected to polynomial analysis of variance with water types and sampling times as factors for all measured variables except for percent deuterated water in the drying roots water and soil water content measured at the end of each sampling time. Percent deuterated water in the drying roots water was analysed with sampling times as the main factor. Soil water content data was analysed by considering pot sides another factor with water types and sampling times. Data were analysed using Genstat $8^{\text {th }}$ edition (PC/ Windows XP), Lawes Agricultural Trust (Rothamsted Experimental Station). Treatments means were considered significantly different at the $5 \%$ level of probability using Tukey's HSD test.

\section{Results}

\section{Water content $(\%$, vol. $)$}

The volumetric water content measured at the end of each sampling time was not significantly different between control and treated plants $(P=0.907)$ (Table 1a) but differed significantly between the wet and the dry side of the pot $(P<0.001)$ (Table $1 \mathrm{~b})$. The polynomial analysis of variance revealed a significant decrease in the water content over time $(P=0.004)$, with a quadratic effect $(P=0.002)$. The non-linear relationship was mainly due to high soil water content in one of the control plants harvested after $24 \mathrm{~h}$ of water application.
Of the possible interactions, pot side $\mathrm{x}$ sampling time interaction significantly affected the water content of the pots $(P=0.005)$, with a linear effect $(P<0.001)$ (Table $1 \mathrm{~b})$. Tukey's test revealed that water content on the wet side was significantly higher from the drying side of the pot for all sampling times. Although water content of the drying side of the pot was not significantly different between sampling times, the water content of $3 \mathrm{~h}$ sampling time was significantly higher from the water content of 12,18 and $24 \mathrm{~h}$ sampling times on the wet side of the dual pot.

\section{Water utilisation from drying side of the pot (\%)}

The percent of water utilisation from drying side of the pot was not significantly different between control and treated plants $(P=0.563)$, between sampling times $(P=0.354)$, and between control and treated plants over the treatment period $(P=0.942)$ (Table 2).

\section{Stomatal conductance}

Stomatal conductance was not significantly different between

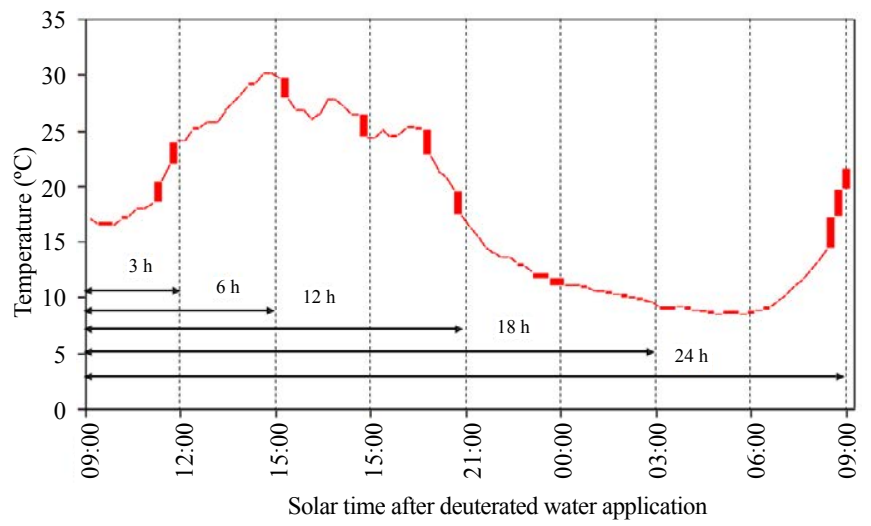

Figure 1: Changes in temperature over the treatment period (2-3 June 2006) following deuterated water application to potatoes (cv. Estima) under glasshouse conditions. Arrows and numbers indicate air temperature experienced by the potato plants during each sampling time (h). Experiment was started at 09:00 am local time.

a) Water type $\times$ sampling time interaction.

\begin{tabular}{|c|c|c|c|c|c|c|}
\hline \multirow{2}{*}{ Water type } & \multicolumn{5}{|c|}{ Sampling time after watering (h) } & \multirow[b]{2}{*}{ Mean } \\
\hline & 3 & 6 & 12 & 18 & 24 & \\
\hline Tap water (control plants) & 31.31 & 30.71 & 27.98 & 28.58 & 30.16 & 29.75 \\
\hline $\begin{array}{l}\text { Deuterated water (treated } \\
\text { plants) }\end{array}$ & 32.13 & 30.04 & 28.53 & 29.24 & 29.15 & 29.82 \\
\hline Mean & 31.72 & 30.38 & 28.25 & 28.91 & 29.65 & \\
\hline
\end{tabular}

b) Pot side $\times$ sampling time interaction.

\begin{tabular}{|c|c|c|c|c|c|c|}
\hline \multirow{2}{*}{ Pot side } & \multicolumn{5}{|c|}{ Sampling time after watering (h) } & \multirow{2}{*}{ Mean } \\
\cline { 2 - 7 } & 3 & 6 & 12 & 18 & 24 & \\
\hline Wet & 40.08 & 37.55 & 34.29 & 34.54 & 34.73 & 36.24 \\
\hline Dry & 23.36 & 23.20 & 22.21 & 23.28 & 24.59 & 23.33 \\
\hline
\end{tabular}

C) Water type $\times$ pot side $\times$ sampling time interaction.

\begin{tabular}{|c|c|c|c|c|c|c|c|}
\hline \multirow{2}{*}{ Water Type } & \multirow{2}{*}{ Pot side } & \multicolumn{5}{|c|}{ Sampling time after watering (h) } & \multirow{2}{*}{ Mean } \\
\cline { 3 - 7 } & 3 & 6 & 12 & 18 & 24 & \\
\hline $\begin{array}{c}\text { Tap water } \\
\text { (control pants) }\end{array}$ & Wet & 39.88 & 37.98 & 34.58 & 23.05 & 34.93 & 36.07 \\
\cline { 2 - 7 } & Dry & 22.75 & 23.45 & 21.38 & 24.18 & 25.40 & 23.43 \\
\hline $\begin{array}{c}\text { Deuterated water } \\
\text { (treated plants) }\end{array}$ & Wet & 40.28 & 37.13 & 34.00 & 36.10 & 34.53 & 36.41 \\
\cline { 2 - 7 } & Dry & 23.98 & 22.95 & 23.05 & 22.38 & 23.78 & 23.23 \\
\hline
\end{tabular}


Citation: Saeed H, Grove IG, Kettlewell PS, Hall NW, Fairchild IJ, et al. (2015) Hydraulic Redistribution from Wet to Drying Roots of Potatoes (Solanum tubersosum L.) During Partial Rootzone Drying. Adv Crop Sci Tech 3: 162. doi:10.4172/2329-8863.1000162

Page 4 of 8

\begin{tabular}{|l|c|c|}
\hline Factor & $\boldsymbol{P}$ value & sed (df=55) \\
\hline Water type & 0.907 & 0.576 \\
\hline Pot side & $<0.001$ & 0.576 \\
\hline Sampling time & 0.004 & \\
\hline Linear & 0.015 & \\
\hline Quadratic & 0.002 & 0.910 \\
\hline Deviations & 0.645 & \\
\hline Water type $\times$ pot side & 0.638 & 0.814 \\
\hline Water type $\times$ sampling time & 0.785 & \\
\hline Water type. linear water & 0.600 & \\
\hline type. quadratic & 0.599 & \multirow{2}{*}{1.288} \\
\hline Deviations & 0.561 & \\
\hline Pot side $\times$ sampling time & 0.005 & \\
\hline Pot side linear & $<0.001$ & \\
\hline Pot side quadratic & 0.277 & \multirow{2}{*}{1.288} \\
\hline Deviations & 0.842 & \\
\hline Water type $\times$ pot side $\times$ sampling time & 0.349 & \\
\hline Water type $\times$ pot sides Linear & 0.244 & \\
\hline Water type $\times$ pot sides Quadratic & 0.900 & \multirow{2}{*}{1.821} \\
\hline Deviations & 0.217 & \\
\hline CV & $8.6 \%$ & \\
\hline
\end{tabular}

Table 1: Volumetric water content (\%) of dual pots measured at the end of each sampling time along with all possible interactions of glasshouse grown potatoes of the cv. Estima.

control and treated plants $(P=0.802)$ (Table 3 ) but differed significantly over the treatment period $(P<0.001)$ (Figure 2$)$ with a linear and quadratic relationship; both with $P<0.001$. Although the deviation remained significant $(P<0.001)$, the quadratic relationship described the stomatal conductance response better as it reflected the biological response of plants with the time of the day. Stomatal conductance measured during daytime at 12:00 $\mathrm{h}$ after $3 \mathrm{~h}$ of water application was significantly higher from all other sampling times. The lowest stomatal conductance $(23.2 \mathrm{mmolm}-2 \mathrm{~s}-1)$ was, however, measured in plants harvested after $18 \mathrm{~h}$ of water application at dawn. There was no significant water type $\mathrm{x}$ sampling time interaction effect on stomatal conductance $(P=0.226)$ (Table 3$)$.

\section{Leaf water potential}

There were no significant differences between control and treated plants for leaf water potential $(P=0.910)$ (Table 4$)$. Leaf water potential, however, differed significantly between the sampling times $(P<0.001)$, with a cubic effect $(\mathrm{P}<0.001)$ (Figure 3$)$. Sampling times $3 \mathrm{~h}$ and $6 \mathrm{~h}$ were statistically similar to each other for leaf water potential but were significantly different from rest of the sampling times. The higher (less negative) leaf water potential of $-222.7 \mathrm{kPa}$ measured in plants harvested at dawn after $18 \mathrm{~h}$ of water application was only found to be non-significant with leaf water potential of the plants harvested in the morning at 09:00 am after $24 \mathrm{~h}$ of water application. Water type $\mathrm{x}$ sampling time interaction effect was found to be non- significant on leaf water potential of the plants $(P=0.344)$ (Table 4$)$.

\section{Isotopic composition $(\delta 2 \mathrm{H}, \%)$ of water of 'drying roots'}

The rate and pattern of water redistribution cannot be described from variations in the $\delta^{2} \mathrm{H}$ values between the sampling times as mean $\delta^{2} \mathrm{H}$ value of each sampling time is an average of control and treated plants $\delta^{2} \mathrm{H}$ values. The $\delta^{2} \mathrm{H}$ values of control plants (received tap water) predominantly reflect natural changes in isotope ratios of root water over time and cannot be used to describe the water redistribution

pattern over the treatment period, only $\delta^{2} \mathrm{H}$ values of the treated plants appear to be more applicable and reliable in describing such trends. Changes in $\delta^{2} \mathrm{H}$ values of the water extracted from 'drying roots' of control and treated plants are, therefore, described separately over the treatment period.

The isotopic composition $\left(\delta^{2} \mathrm{H}, \%\right)$ of water extracted from 'drying roots' was significantly different between control and treated plants $(P<0.001)$ (Table 5$)$, water of the treated plants being $34.9 \%$ isotopically heavier relative to the control plants. The effect of water type $\mathrm{x}$ sampling time interaction on $\delta^{2} \mathrm{H}$ values of water extracted from 'drying roots' was found close to the level of significance $(P=0.052)$ with a quadratic relationship $(P=0.015)$ (Figure 4$)$. The deuterium concentration-time curves for control and treated plants show that deuterated water moved to the drying half of the root system after $3 \mathrm{~h}$ of water application, indicated by relatively higher 'drying roots' water $\delta^{2} \mathrm{H}$ values of the treated plants than the control plants (Figure 4).

The deuterium concentration, however, reached a peak after 12 $\mathrm{h}$ of water application, which remained relatively constant until 18

\begin{tabular}{|c|c|c|c|c|c|c|}
\hline \multirow[t]{2}{*}{ Water type } & \multicolumn{5}{|c|}{ Sampling time after watering (h) } & \multirow[t]{2}{*}{ Mear } \\
\hline & 3 & 6 & 12 & 18 & 24 & \\
\hline $\begin{array}{c}\text { Tap water } \\
\text { (control pants) }\end{array}$ & 18.3 & 17.3 & 15.9 & 14.9 & 15.2 & 16.3 \\
\hline $\begin{array}{c}\text { Deuterated water } \\
\text { (treated plants) }\end{array}$ & 18.8 & 17.2 & 15.4 & 16.3 & 17.1 & 16.9 \\
\hline Mean & 18.5 & 17.3 & 15.7 & 15.6 & 16.1 & \\
\hline \multicolumn{3}{|c|}{ Factor } & \multicolumn{2}{|c|}{$P$ value } & \multicolumn{2}{|c|}{$\operatorname{sed}(d f=26)$} \\
\hline \multicolumn{3}{|c|}{ Water type } & \multicolumn{2}{|c|}{0.563} & \multicolumn{2}{|c|}{1.048} \\
\hline \multicolumn{3}{|c|}{ Sampling time } & \multicolumn{2}{|c|}{0.354} & \multirow{4}{*}{\multicolumn{2}{|c|}{1.657}} \\
\hline \multicolumn{3}{|c|}{ Linear } & \multicolumn{2}{|c|}{0.110} & & \\
\hline \multicolumn{3}{|c|}{ Quadratic } & \multicolumn{2}{|c|}{0.186} & & \\
\hline \multicolumn{3}{|c|}{ Deviations } & \multicolumn{2}{|c|}{0.984} & & \\
\hline \multicolumn{3}{|c|}{ Water type $\times$ sampling time } & \multicolumn{2}{|c|}{0.942} & \multirow{4}{*}{\multicolumn{2}{|c|}{2.343}} \\
\hline \multicolumn{3}{|c|}{ Water type. Linear } & \multicolumn{2}{|c|}{0.524} & & \\
\hline Water type & Quadrat & & 0.6 & $0.6 / 9$ & & \\
\hline \multicolumn{3}{|c|}{ Deviations } & 0.9 & & & \\
\hline \multicolumn{3}{|c|}{ CV } & \multicolumn{2}{|c|}{$19.9 \%$} & & \\
\hline
\end{tabular}

Table 2: Water utilisation (\%) by glasshouse-grown potatoes (cv. Estima) from drying side of the pot over treatment period.

\begin{tabular}{|c|c|c|c|c|c|c|}
\hline \multirow[t]{2}{*}{ Water Type } & \multicolumn{5}{|c|}{ Sampling time after watering (h) } & \multirow[t]{2}{*}{ Mean } \\
\hline & 3 & 6 & 12 & 18 & 24 & \\
\hline $\begin{array}{l}\text { Tap water (control } \\
\text { pants) }\end{array}$ & 158.8 & 86.5 & 93.2 & 25.0 & 61.5 & 85.0 \\
\hline $\begin{array}{l}\text { Deuterated water } \\
\text { (treated plants) }\end{array}$ & 199.2 & 87.0 & 58.2 & 21.5 & 71.5 & 87.5 \\
\hline \multicolumn{3}{|l|}{ Factor } & \multicolumn{2}{|l|}{$P$ value } & \multicolumn{2}{|c|}{$\operatorname{sed}(d f=26)$} \\
\hline \multicolumn{3}{|l|}{ Water type } & \multicolumn{2}{|l|}{0.802} & \multicolumn{2}{|c|}{9.86} \\
\hline \multicolumn{3}{|l|}{ Sampling time } & \multicolumn{2}{|l|}{$<0.001$} & \multirow{4}{*}{\multicolumn{2}{|c|}{15.58}} \\
\hline \multicolumn{3}{|l|}{ Linear } & \multicolumn{2}{|l|}{$<0.001$} & & \\
\hline \multicolumn{3}{|l|}{ Quadratic } & \multicolumn{2}{|l|}{$<0.001$} & & \\
\hline \multicolumn{3}{|l|}{ Cubic } & \multicolumn{2}{|l|}{0.592} & & \\
\hline \multicolumn{3}{|c|}{ Water type $\times$ sampling time } & \multicolumn{2}{|l|}{0.226} & \multirow{5}{*}{\multicolumn{2}{|c|}{22.04}} \\
\hline \multicolumn{3}{|l|}{ Water type. Linear } & \multicolumn{2}{|l|}{0.473} & & \\
\hline \multicolumn{3}{|c|}{ Water type. Quadratic } & \multicolumn{2}{|l|}{0.045} & & \\
\hline \multicolumn{3}{|l|}{ Water types. Cubic } & \multicolumn{2}{|l|}{0.339} & & \\
\hline \multicolumn{3}{|l|}{ Deviations } & \multicolumn{2}{|l|}{0.707} & & \\
\hline \multicolumn{2}{|l|}{ CV } & & \multicolumn{2}{|l|}{$36.1 \%$} & & \\
\hline
\end{tabular}

Table 3: Stomatal conductance $\left(\mathrm{mmolm}^{-2} \mathrm{~s}^{-1}\right)$ over treatment period of potato plants (cv. Estima) received tap water and deuterated water under glasshouse conditions. 
Citation: Saeed H, Grove IG, Kettlewell PS, Hall NW, Fairchild IJ, et al. (2015) Hydraulic Redistribution from Wet to Drying Roots of Potatoes (Solanum tubersosum L.) During Partial Rootzone Drying. Adv Crop Sci Tech 3: 162. doi:10.4172/2329-8863.1000162

Page 5 of 8

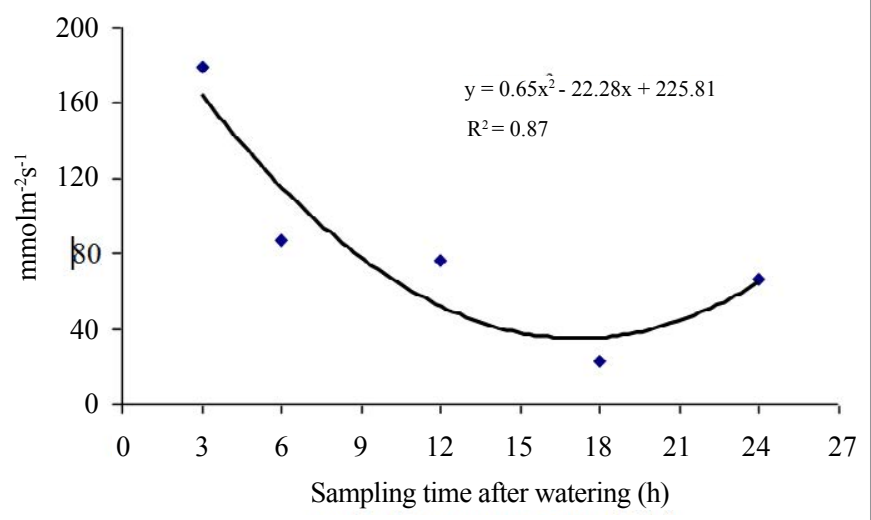

Figure 2: Diurnal changes in stomatal conductance $\left(\mathrm{mmolm}^{-2} \mathrm{~s}^{-1}\right)$ following deuterated water application to glasshouse grown potatoes (cv Estima) at 09:00 am local time.

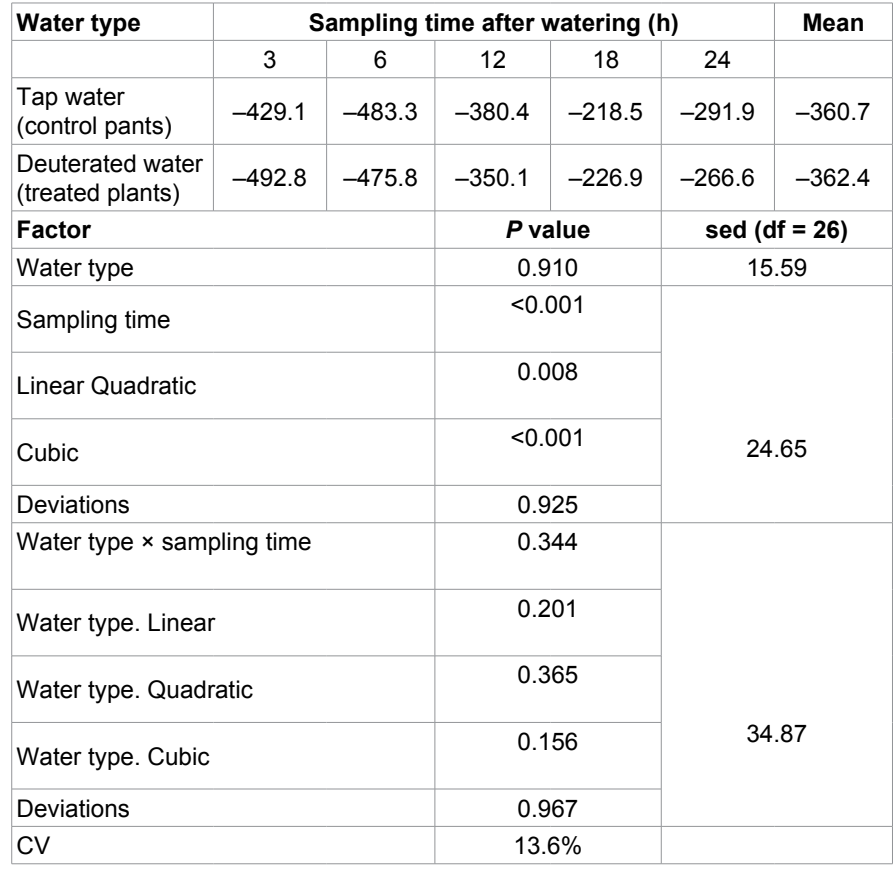

Table 4: Leaf water potential $(\mathrm{kPa})$ measured over time following deuterated water application to glasshouse grown potatoes of the cv. Estima.

$\mathrm{h}$ and then showed a declining trend, with the lowest $\delta^{2} \mathrm{H}$ value of $-33.4 \%$ in plants harvested after $24 \mathrm{~h}$ of water application. The 'drying roots'water $\delta^{2} \mathrm{H}$ values of the control plants were not significantly between the sampling times and varied from -53.3 to $-63.7 \%$ (Figure 4 ), with a mean of $-57.6 \%$ (Table 5). Root water of the control plants was $6.6 \%$ isotopically lighter than the source irrigation water $\delta^{2} \mathrm{H}$ value of $-51 \%$, indicating the liberation of organically bound hydrogen into the bulk root water due to the breakdown of either plant tissues or sap carbohydrates to some extent at high distillation temperature [33].

\section{Percent deuterated water in the 'drying roots' water}

The proportion of deuterated water in the water extracted from 'drying roots' of the treated plants was significantly different over the time course of the study $(P=0.046)$ (Figure 5). Figure 5 shows a steady increase in the redistribution of deuterated water from the roots in the wet soil to the roots in the drying soil from 6 to $18 \mathrm{~h}$ of water application, with the highest deuterium concentration of $3.48 \%$ in plants harvested after $18 \mathrm{~h}$ of water application at dawn. The percent deuterated water, however, declined to $1.57 \%$ in plants harvested in the morning at 09:00 am after $24 \mathrm{~h}$ of water application. The small proportion of the deuterated water in 'drying roots' of the treated plants indicates that

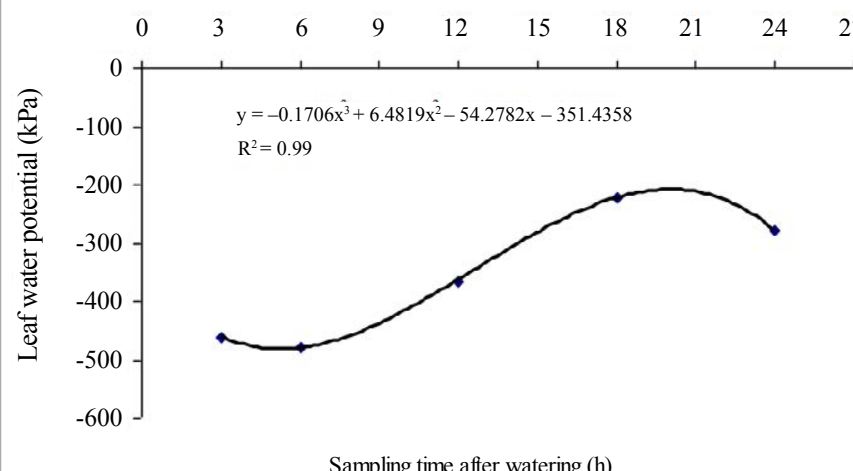

Figure 3: Diurnal changes in leaf water potential $(\mathrm{kPa})$ following deuterated water application to glasshouse grown potatoes (cv Estima) at 09:00 am local time.

\begin{tabular}{|c|c|c|}
\hline \multicolumn{2}{|l|}{ Water type } & $\Delta^{2} \mathrm{H}(\%)$ \\
\hline \multicolumn{2}{|l|}{ Tap water (control plants) } & -57.6 \\
\hline \multicolumn{2}{|c|}{ Deuterated water (treated plants) } & -22.7 \\
\hline Factor & $P$ value & $\operatorname{sed}(d f=26)$ \\
\hline Water type & $<0.001$ & 2.66 \\
\hline Sampling time & 0.653 & \multirow{4}{*}{4.21} \\
\hline Linear & 0.275 & \\
\hline Quadratic & 0.350 & \\
\hline Deviations & 0.852 & \\
\hline Water type $\times$ sampling time & 0.052 & \multirow{5}{*}{5.96} \\
\hline Water type. Linear & 0.302 & \\
\hline Water type. Quadratic & 0.015 & \\
\hline Deviations & 0.248 & \\
\hline CV & $21.0 \%$ & \\
\hline
\end{tabular}

Table 5: Mean $\delta^{2} \mathrm{H}$ values (\%) of water extracted from 'drying roots' of the control (received tap water) and the treated (received deuterium-enriched water) plants of potato cv. Estima.

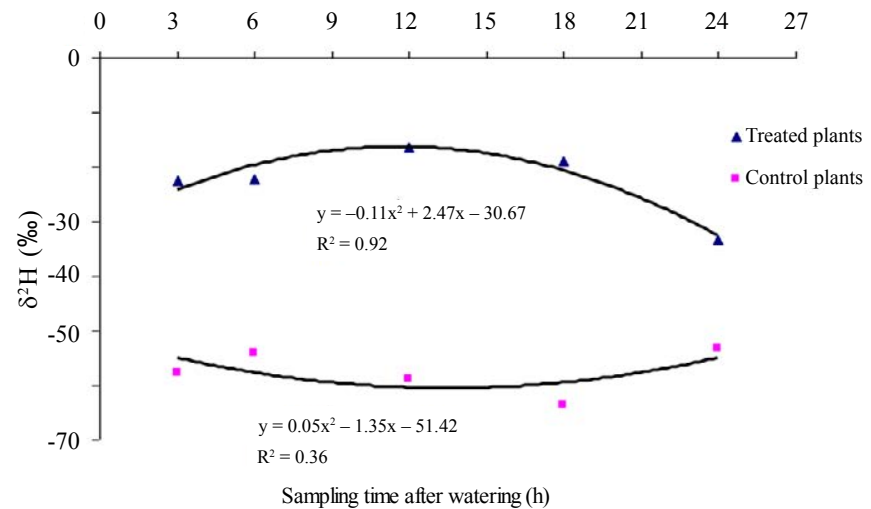

Figure 4: Time course changes in $\delta^{2} \mathrm{H}(\%)$ values of water extracted from 'drying roots' of control and treated potato plants (cv. Estima) grown under glasshouse conditions. Experiment was started at 09:00 am local time. 


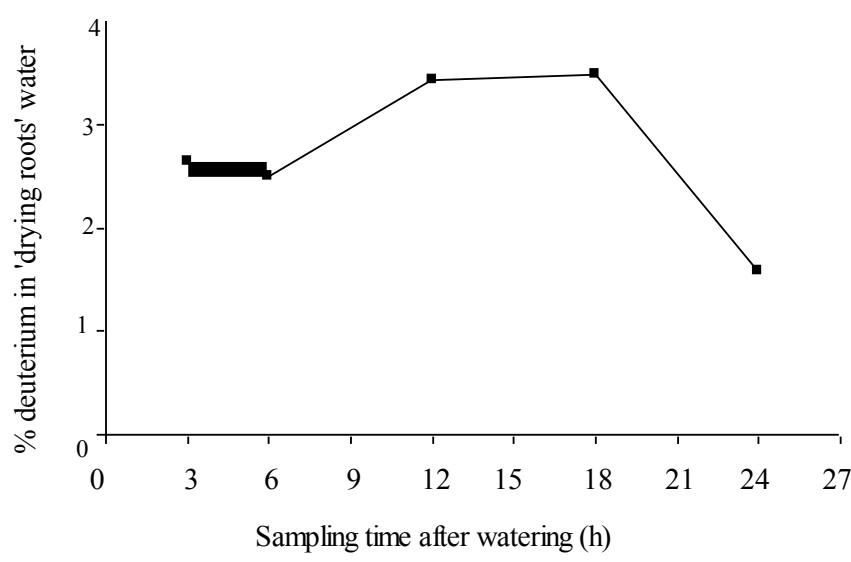

Figure 5: Estimated percentages of deuterated water in the water extracted from 'drying roots' of treated potato plants (cv. Estima) under glasshouse conditions. Experiment was started at 09:00 am local time. $P=0.046$; sed $=0.584 ; \mathrm{CV}(\%)=30.3$.

the 'drying roots' were less dependent on the water of the wet soil but were largely relying on the water existing in the drying soil (Figure 5).

\section{Discussion}

Irrespective of the sampling time, $\delta^{2} \mathrm{H}$ values of the 'drying roots' of the treated plants remained negative relative to the standard (VSMOW). There could be several reasons. Firstly, the negative $\delta^{2} \mathrm{H}$ values might be associated with the root sample size. Whole root system growing in the drying soil was used to extract water for isotope analysis. Although the whole root system was used to reduce bias in the results, the existing water in the roots, absorbed from the soil previously watered with tap water $\left(\delta^{2} \mathrm{H}=-51 \%\right)$, might have diluted the deuterium concentration of the redistributed water. Secondly, there is a possibility that the quantity of water absorbed by roots from the irrigated side of the pot was perhaps sufficient to hydrate the above-ground plant parts but not sufficient enough to hydrate all roots in the drying soil given the relatively short time period over which the samplings were taken. Thirdly, the liberation of hydrogen $(\mathrm{H})$ from breaking down of plant tissues or sap carbohydrates at high temperature of the azeotropic distillation technique might have modified the $\delta^{2} \mathrm{H}$ values of water [31]. Finally, deuterium might have been retained in the tissue matrix, or mixed and exchanged with hydrogen atoms of cell tissues in different compartments of the above-ground plant parts [34], which could have resulted in either loss of deuterium or slowed down the deuterium content reaching the roots growing in the drying soil, thereby reducing deuterium concentration. Schiegl and Vogel [35] also reported depletion in the $\mathrm{D} / \mathrm{H}$ ratio $\left(\delta^{2} \mathrm{H}\right)$ of several percent during the conversion of water to organic matter in living plants. The results, therefore, need to be read cautiously.

The results indicate that water moved from roots in the wet soil to roots in the drying soil as the root water of the treated plants was isotopically heavier relative to the control plants. Although there was an indication of water redistribution, the magnitude of this redistribution, however, was less distinct between sampling times. Surprisingly, the treated plants harvested after $3 \mathrm{~h}$ and $6 \mathrm{~h}$ of water application at 12:00 and 15:00 h had higher $\delta^{2} \mathrm{H}$ values of the 'drying roots' water relative to the control plants, showing water movement of $2.63 \%$ and $2.50 \%$ from wet soil roots to 'drying roots'. Physiologically, plants of these sampling times had higher stomatal conductance and lower leaf water potential (more negative) (Figures 2 and 3 ), indicating high evaporative demands of the plants relative to other sampling times. Under high evaporative demands, water evaporation in the stomatal chamber develops a highly negative pressure (i.e. tensions up to $-1000 \mathrm{kPa}$ ) in the xylem vessels, which draws water from the roots up into the aerial parts [36] and is distributed to the cells that are losing water, predominantly by the apoplastic pathway [37].

During this unidirectional water movement, the reasons for this higher $\delta 2 \mathrm{H}$ values in the 'drying roots' are not clear. Since the wet and the drying roots had originated from the same stem base, there is a possibility that deuterated water entering the stem might have moved across (or around) the stem laterally from the root-stem interface [20] and then transported downwards into 'drying roots', contrary to the direction of the transpiration stream. Brooks et al. [17] studied hydraulic redistribution of woody perennials and pointed out that the traverse flow across (around) the trunk and then reversal into roots and soils on the non-irrigated side was possible provided resistances to hydraulic conductance across the tissues of the trunk were greater that roots. Lateral movement of deuterated water between the sides of the pot at the time of application could be the other possibility but this potential source of error was eliminated by applying water away from the stem base at a slow trickle. This method of water application effectively restricted water movement within the wet soil column of the pot as there were no visible signs of lateral water movement between the pot sides.

Several researchers have successfully demonstrated that hydraulic redistribution usually occurs at night when transpiration diminished sufficiently to allow water potential of the roots to exceed that of the other plant parts or the drier portions of the soil profile $[7,17,29,38$ 40]. In this study, the plants harvested after $18 \mathrm{~h}$ of water application at dawn $(03: 00 \mathrm{am})$ had the lowest stomatal conductance and highest leaf water potential (less negative) but the amount of water redistributed to the drying roots was only $3.48 \%$ (Figure 5 ). This suggests that the hydraulic resistances encountered by water being redistributed from roots in the wet soil to roots in the drying soil through shoots were probably high [29], thereby resulting in reduced water transport into the 'drying roots'. It is also postulated that reduced stomatal conductance and higher leaf water potential (less negative) coupled with warmer and drier conditions at night (increased vapour pressure deficit) were perhaps still high enough to sustain a water potential gradient between the soil and roots to extract water to refill the aboveground plant storage compartments [29]. The above-ground plant parts refilling demand may have indirectly limited or reduced the magnitude of hydraulic redistribution by creating strong sinks for water within the transpiring foliage than existed in the roots growing in the drying soil. Other possible explanation could be that hydraulic lift was also occurring simultaneously. Thus, the 'drying roots' were probably being rehydrated both from above-ground plant parts due to hydraulic redistribution and from deeper moist soil layers due to hydraulic lift, thereby neutralising the deuterium concentration to some extent. Hultine et al. [41] found that the magnitude of hydraulic redistribution was greater in roots when night-time vapour pressure deficit was low.

The isotopic composition of the root water declined after $24 \mathrm{~h}$ of water application, which corresponded to daytime 09:00 am in the morning. The reasons for this decline are not clear. It is likely that the 'drying roots' were also supplying water to the shoot to meet the plant transpirational demand on a bright and hot morning with an air temperature above $20^{\circ} \mathrm{C}$ (Figure 1). This is supported by the increased stomatal conductance and a lower leaf water potential (more negative) of this sampling time relative to the $18 \mathrm{~h}$ sampling time (Figures 2 
Citation: Saeed H, Grove IG, Kettlewell PS, Hall NW, Fairchild IJ, et al. (2015) Hydraulic Redistribution from Wet to Drying Roots of Potatoes (Solanum tubersosum L.) During Partial Rootzone Drying. Adv Crop Sci Tech 3: 162. doi:10.4172/2329-8863.1000162

and 3). As a result of this, the deuterium concentration $\left(\delta^{2} \mathrm{H}\right)$ of over nightly redistributed water might have been diluted by water absorbed from the drying soil or a portion of the redistributed water might have been supplied to the shoot before sampling (Table 2), thereby showing a decline in water redistribution from $3.48 \%$ to $1.57 \%$ relative to the 18 $\mathrm{h}$ sampling time. Alternatively, the decline in deuterium concentration could partly be due to inherent uncertainties associated with the sampling, distillation or analytical technique. Soil water content was measured at the end of each sampling time from both sides of the dual pot to quantify its effect on hydraulic redistribution. On average, the soil water content remained above $36 \%$ on the irrigated side and above $23 \%$ on the dry side of the pot (Table $1 \mathrm{~b}$ ). Theoretically, substantial water redistribution should have occurred due to the unequal soil water content between the wet and the dry part of the root system but this was not observed even during periods of low transpiration (i.e. night-time) (Figure 2). The magnitude of the hydraulically redistributed water was perhaps largely dependent on the hydraulic resistances encountered by water during the cell-to-cell pathway [42].

The water utilisation pattern indicated that the plants predominantly utilised water from the irrigated side of the dual, as expected. Despite the wet side being the dominant source of water use, the small changes in $\delta^{2} \mathrm{H}$ values of the 'drying roots' water between the sampling times suggest less dependency of the 'drying roots' on the wet side of the root system. Further, water supplying ability of the 'drying roots' to the shoot (Table 2) may have deterred water redistribution substantially or water absorbed by these roots from the soil may have altered the isotope ratio $\left(\delta^{2} \mathrm{H}\right)$ of root water upon mixing with the redistributed water. Based on the results, we suggest the occurrence of hydraulic redistribution in potatoes during partial root zone drying at a limited rate. The limited water redistribution would probably be of little significance in the survival of roots present in the upper drier portion of the soil under higher water demanding conditions but its role in sending the chemical signals to the shoot to conserve water by reducing transpiration would be of particular significance during drying periods of partial rootzone drying. It is planned to study this mechanism over days by observing the movement of deuterium from wet roots to stems, leaves and then to the roots growing in the drying soil column for better understanding of the hydraulic redistribution mechanism under partial rootzone drying.

\section{Acknowledgements}

The first author thanks Harper Adams University College, Shropshire, UK, for funding this research project.

\section{References}

1. Wesseling JG, Feddes RA (2006) Assessing crop water productivity from field to regional scale. Agricultural Water Management 86: 30-39.

2. Jefferies RA (1993) Response of potato genotypes to drought. I. Expansion of individual leaves and osmotic adjustment. Annals of Applied Biology 122: 93-104.

3. Frensch J (1997) Primary responses of root and leaf elongation to water deficits in the atmosphere and soil solution. Journal of Experimental Botany 48: 985999.

4. Heuer B, Nadler A (1998) Physiological response of potato plants to soil salinity and water deficit. Plant Science 137: 43-51.

5. Sharp RE, Davies WJ (1985) Root growth and water uptake by maize plants in drying soils. Journal of Experimental Botany 36: 1441-1456.

6. Zegada-Lizarazu W, lijima M (2004) Hydrogen stable isotope analysis of water acquisition ability of deep roots and hydraulic lift in sixteen food crop species. Plant Production Science 7: 427-434.

7. Richards JH, Caldwell MM (1987) Hydraulic lift: substantial nocturnal water transport between soil layers by Artemisia tridentate roots. Oecologia 73: 486489
8. Caldwell MM, Richards JH (1989) Hydraulic lift: water efflux from upper roots improves effectiveness of water uptake by deep roots. Oecologia 79: 1-5.

9. Burgess SSO, Adams MA, Turner NC, Ong CK (1998) The redistribution of soil water by tree root systems. Oecologia 115: 306-311.

10. Sakuratani T, Aoe T, Higuchi H (1999) Reverse flow in roots of Sesbania rostrata measured using the constant power heat balance method. Plant, Cell and Environment 22: 1153-1160.

11. Meinzer FC, Clearwater MJ, Goldstein G (2001) Water transport in trees: current perspectives, new insights and some controversies. Environmental and Experimental Botany 45: 239-262.

12. Smith DM, Jackson NA, Roberts JM, Ong CK (1999) Reverse flow in tree roots and downward siphoning of water by Grevillea robusta. Functional Ecology 13 256-264.

13. Schulze ED, Caldwell MM, Canedell J, Mooney HA, Jackson RB, et al. (1998) Downward flux of water through roots (i.e. inverse hydraulic lift) in dry Kalahari sands. Oecologia 115: 460-462.

14. Scholz FG, Bucci SJ, Goldstein GH, Meinzer FC, Franco AC (2002) Hydraulic redistribution of soil water by neotropical savanna trees. Tree Physiology 22 603-612.

15. Hultine KR, Williams DG, Burgess SSO (2003) Contrasting patterns of hydraulic redistribution in three desert phreatophytes. Oecologia 135: 167-175.

16. Brooks JR, Meinzer FC, Warren JM, Domec J (2006) Hydraulic redistribution in a Douglas-fir forest: lessons from system manipulation. Plant, Cell and Environment 29: 138-150.

17. Brooks JR, Meinzer FC, Coulombe R, Gregg J (2002) Hydraulic redistribution of soil water during summer drought in two contrasting Pacific Northwest coniferous forests. Tree Physiology 22: 1107-1117.

18. Loveys BR, Dry PR, Stoll M, McCarthy MG (2000) Using plant physiology to improve the water use efficiency of horticultural crops. Acta Horticulturae 537 187-197.

19. Caldwell MM, Dawson TE, Richards JH (1998) Hydraulic lift: consequences of water efflux from the roots of plants. Oecologia 113: 151-161.

20. Smart DR, Carlisle E, Goebel M, Nunez BA (2005) Transverse hydraulic redistribution by a grapevine. Plant, Cell and Environment 28: 157-166.

21. Jackson RB, Sperry JS, Dawson TE (2000) Root water uptake and transport using physiological processes in global predictions. Trends in Plant Science 5: $482-488$.

22. Loveys BR, Dry PR, Stoll M, McCarthy MG (2000) Using plant physiology to improve the water use efficiency of horticultural crops. Acta Horticulturae 537 187-197.

23. Firman DM (1988) Field measurement of the photosynthetic rate of potatoes grown with different amounts of nitrogen fertilizer. Journal of Agricultural Science 111: 85-90.

24. Basu PS, Sharma A, Garg ID, Sukumaran NP (1999) Tuber sink modifies photosynthetic response in potato under water stress. Environmental and Experimental Botany 42: 25-39.

25. Scholander PF, Hammel HT, Bradstreet ED, Hemmingsen EA (1965) Sap pressure in vascular plants. Science 148: 339-346.

26. Böhm W (1979) Methods of Studying Root Systems. ( $1^{\text {st }}$ edn) Springer-Verlag, Berlin and New York.

27. Peñuelas J, Fielella I (2003) Deuterium labelling of roots provides evidence of deep water access and hydraulic lift by Pinus nigra in a Mediterranean forest of NE Spain. Environmental and Experimental Botany 49: 201-208.

28. Thorburn PJ, Mensforth LJ (1993) Sampling water from alfalfa (Medicago sativa) for analysis of stable isotopes of water. Communications in Soil Science and Plant Analysis 24: 549-557.

29. Stoll M, Loveys B, Dry P (2000) Hormonal changes induced by partial rootzone drying of irrigated grapevine. Journal of Experimental Botany 51: 1627-1634.

30. Revesz K, Woods P (1990) A method to extract soil water for stable isotope analysis. Journal of Hydrology 115: 397-406.

31. Allison GB, Gat JR, Leaney FWJ (1985) The relationship between deuterium and oxygen-18 delta values in leaf water. Chemical Geology 58: 145-156.

32. Leaney FW, Osmond CB, Allison GB, Ziegler H (1985) Hydrogen-isotope 
Citation: Saeed H, Grove IG, Kettlewell PS, Hall NW, Fairchild IJ, et al. (2015) Hydraulic Redistribution from Wet to Drying Roots of Potatoes (Solanum tubersosum L.) During Partial Rootzone Drying. Adv Crop Sci Tech 3: 162. doi:10.4172/2329-8863.1000162

composition of leaf water in C3 and C4 plants: its relationship to the hydrogenisotope composition of dry matter. Planta 164: 215-220

33. Walker CD, Lance RMC (1991) The fractionation of $2 \mathrm{H}$ and 180 in leaf water of barley. Australian Journal of Plant Physiology 18: 411-425.

34. Calder IR (1991) Implications and assumptions in using the "total counts" and convection-dispersion equations for tracer flow measurements - with particular reference to transpiration measurements in tress. Journal of Hydrology 125 149-158.

35. Schiegl WE, Vogel JC (1970) Deuterium content of organic matter. Earth and Planetary Science Letters 7: 307-313.

36. Steudle E (2001) The cohesion-tension mechanism and the acquisition of water by plant roots. Annual Review of Plant Physiology and Plant Molecular Biology 52: 847-875

37. Steudle E, Peterson CA (1998) How does water get through roots? Journal of Experimental Botany 49: 775-788.
38. Dawson TE (1993) Hydraulic lift and water use by plants: implication for water balance, performance and plant-plant interactions. Oecologia 95: 565-574.

39. Yoder CK, Nowak RS (1999) Hydraulic lift among native plant species in the Mohave Desert. Plant and Soil 215: 93-102.

40. Millikin IC, Bledsoe CS (2000) Seasonal and diurnal patterns of soil wate potential in the rhizosphere of blue oaks: evidence for hydraulic lift. Oecologia 125: 459-465.

41. Hultine KR, Williams DG, Burgess SSO (2003) Contrasting patterns of hydraulic redistribution in three desert phreatophytes. Oecologia 135: 167-175.

42. Steudle E (2001) The cohesion-tension mechanism and the acquisition of water by plant roots. Annual Review of Plant Physiology and Plant Molecular Biology 52: 847-875.
Citation: Saeed H, Grove IG, Kettlewell PS, Hall NW, Fairchild IJ, et al. (2015) Hydraulic Redistribution from Wet to Drying Roots of Potatoes (Solanum tubersosum L.) During Partial Rootzone Drying. Adv Crop Sci Tech 3: 162 doi:10.4172/2329-8863.1000162
Submit your next manuscript and get advantages of OMICS Group submissions

Unique features:

- User friendly/feasible website-translation of your paper to 50 world's leading languages

Audio Version of published paper

Digital articles to share and explore

Special features:

400 Open Access Journals

30,000 editorial team

21 days rapid review process

Quality and quick editorial, review and publication processing

Indexing at PubMed (partial), Scopus, EBSCO, Index Copernicus and Google Scholar etc

- Sharing Option: Social Networking Enabled

- Authors, Reviewers and Editors rewarded with online Scientific Credits

Better discount for your subsequent articles

Submit your manuscript at: http://www.omicsonline.org/submission/ 